Article

\title{
(Ti,Cr)C-Based Cermets with Varied Nicr Binder Content via Elemental SHS for Perspective Cutting Tools
}

\author{
Stepan Vorotilo ${ }^{1, *}$, Philipp V. Kiryukhantsev-Korneev ${ }^{1, * \mathbb{C}}$, Boris S. Seplyarskii ${ }^{2}$, \\ Roman A. Kochetkov ${ }^{2}$, Nail I. Abzalov ${ }^{2}$, Ivan D. Kovalev ${ }^{2}$, Tatyana G. Lisina ${ }^{2}$ \\ and Alexander A. Zaitsev ${ }^{1}$ \\ 1 Department of Powder Metallurgy and Functional Coatings, National University of Science and Technology \\ «MISiS», 119049 Moscow, Russia; aazaitsev@bk.ru \\ 2 Laboratory of the Combustion of Dispersed Systems, Merzhanov Institute of Structural Macrokinetics and \\ Materials Science, 142432 Chernogolovka, Russia; seplb1@mail.ru (B.S.S.); numenor@list.ru (R.A.K.); \\ abzalov396@mail.ru (N.I.A.); kovalev@ism.ac.ru (I.D.K.); lisina@ism.ac.ru (T.G.L.) \\ * Correspondence: stepan.vorotylo@gmail.com (S.V.); kiruhancev-korneev@yandex.ru (P.V.K.-K.)
}

Received: 29 April 2020; Accepted: 16 May 2020; Published: 20 May 2020

\begin{abstract}
The effects of granulation of reactive mixtures Ti-Cr-C and Ti-Cr-C-Ni on the combustion temperature and velocity, as well as phase composition and mechanical properties (crushing ability) of combustion products, were studied. Granulation was associated with a 1.5-fold increase in combustion velocity, caused by a nearly 10 -fold increase in gas permeability. Secondary reactions between $\mathrm{TiC}, \mathrm{Cr}_{7} \mathrm{C}_{3}$, and molten $\mathrm{Ni}$ led to the formation of (Ti,Cr)C FCC solid solution and $\mathrm{Ni}_{2.88} \mathrm{Cr}_{1.12}$ intermetallics. After the combustion of Ti-Cr-C-Ni mixtures, prolonged fluorescence was registered, suggesting the exothermic nature of secondary phase formation reactions. The introduction of the nickel binder decreased the content of $\mathrm{Cr}$ in the solid solution ( $\mathrm{Ti}, \mathrm{Cr}) \mathrm{C}$ owing to the formation of the $\mathrm{Ni}_{2.88} \mathrm{Cr}_{1.12}$ phase. To prevent the $\mathrm{Cr}$ depletion from the carbide solid solution, $\mathrm{Ni}-20 \% \mathrm{Cr}$ binder was added to the granulated $80 \%(\mathrm{Ti}+\mathrm{C}) / 20 \%(3 \mathrm{Cr}+2 \mathrm{C})$ mixture. Combustion of granulated mixture yielded brittle porous sinter cake, which was easy to crush and mill, whereas the combustion products from the powdered mixtures were more ductile and harder to crush.
\end{abstract}

Keywords: milling; composites; microstructure; carbides

\section{Introduction}

Widely used in the machining industry, cermets consist of a hard ceramic phase and ductile metallic binder, which endow these materials with high hardness and ductility [1-3]. A multitude of compositions was developed, including $\mathrm{TiC} / \mathrm{Ni}, \mathrm{TiC} / \mathrm{Fe}, \mathrm{TiC} / \mathrm{NiCr}, \mathrm{ZrC} / \mathrm{W}, \mathrm{SiC} / \mathrm{CoSi}{ }_{2}$, and $\mathrm{SiC} / \mathrm{AlSi}$ [3]. Transitional metal carbides are usually employed as the ceramic phase owing to their outstanding hardness, stiffness, and refractoriness [4-10]. Titanium carbide (TiC) is often the ceramic of choice owing to its low density $\left(4.93 \mathrm{~g} / \mathrm{cm}^{3}\right)$ and friction coefficient, high solvency with other carbides, high melting point $\left(3067^{\circ} \mathrm{C}\right)$, elastic modulus ( $410 \mathrm{GPa}$ to $\left.450 \mathrm{GPa}\right)$, thermal conductivity $\left(30 \times 10^{6} \mathrm{~S} / \mathrm{cm}\right.$ ), thermal stability, as well as hardness surpassing tungsten carbide (WC) for more than $30 \%$ [11-15].

The development of TiC-based cermets began shortly after the patenting of first classical WC-Co hardmetals. TiC-based cermets proved to be superior to WC-Co counterparts regarding resistance against wear and oxidation, as well as cutting performance [16-19], but remained definitely inferior in toughness [4,20-22]. To improve the mechanical properties of TiC-based cermets, alloying is widely used [19,23-27]. 
The addition of carbon can beneficially affect the mechanical properties of cermets [28-30], in particular, owing to the reduction of residual oxides [31-33] and improved wettability of the ceramic phase by the binder [29,34-43].

Tungsten-free TiC-based cermets are continuing to gain traction in both research and industrial-scale production. In Japan, TiC-based cermets account for over $30 \%$ of the metal cutting grades $[44,45]$. The first TiC-based cermets, marketed by the Metallwerk Plansee, Austria, were based on TiC/Mo $/ \mathrm{M}_{2} \mathrm{C}$ with a nickel or nickel-chromium binder. The addition of $\mathrm{Mo}_{2} \mathrm{C}$ was intended to improve the wettability of Ti-based ceramics by the nickel binder [46-48].

Since then, binders based on various transient elements such as $\mathrm{Fe}, \mathrm{Cr}, \mathrm{Ni}, \mathrm{Co}, \mathrm{Mo}$, and their alloys were adapted to produce TiC-based cermets [4,49-52]. Ni-based alloys demonstrate particularly high corrosion and wear resistance and are characterized by a low wettability angle on TiC substrate, which is conducive for the densification of TiC-Ni cermets during liquid phase sintering [53]. One of the most commonly used Ni-based alloys is $\mathrm{NiCr}(80 \% \mathrm{Ni}-20 \% \mathrm{Cr})$, which can be used as the binder for TiC to attain high hardness, wear, and corrosion resistance, as well as reasonable toughness of the composite [54].

Solid solution $(\mathrm{Ti}, \mathrm{Cr}) \mathrm{C}$, while retaining the main advantages of $\mathrm{TiC}$, possesses higher oxidation resistance owing to the formation of $\mathrm{Cr}_{2} \mathrm{O}_{3}$ [55]. To diminish the brittleness and enhance the adhesion during the deposition of protective coatings, metallic binders ( $\mathrm{Ni}, \mathrm{Mo}, \mathrm{NiCr}, \mathrm{Cu}$, and so on) are added to the carbide (Ti,Cr)C-based powders, as demonstrated Borisov et al. [56] and Varma and Mukasyan [57].

Carbide solid solution-based composites can be produced using the powder metallurgy, hot isostatic pressing, spark plasma sintering, and self-propagating high-temperature synthesis (SHS) $[58,59]$.

Numerous works [60-73] outlined the advantages of SHS materials for thermal spraying of protective coatings based on carbides and related composites. SHS stands out in terms of its low energy consumption, simplicity, high productivity, purity, and uniformity of the products obtained in one technological cycle. At equal coating properties, SHS powders provide 20-25-fold energy savings and half the labor input as compared with conventional methods of powders preparation. [74]. The high exothermal effect of $\mathrm{TiC}$ formation allows for a large choice of metallic binder compositions and concentrations as the binder usually acts as an inert diluent in the combustion front and the primary reaction has to be exothermic enough to allow for the self-propagation reaction to occur. Several studies investigated the use of SHS for the synthesis of $\mathrm{TiC}-\mathrm{Cr}$, $\mathrm{TiC}-\mathrm{Ni}$, and $\mathrm{TiC}-\mathrm{NiCr}$ composite powders $[61,62,70,75,76]$.

SHS of titanium-chromium carbide from the mixtures of titanium, carbon, and nickel-chromium alloy powders was suggested by Zhang et al. $[77,78]$ and implemented at semi-industrial scale by Vlasov et al. [79]. However, the SHS of the titanium-chromium carbide with a metallic binder from powders mixtures produces strong and ductile sinter cakes, requiring a subsequent higher-energy ball milling and increasing the pollution of the products by the wear products of milling bodies.

In this work, we propose the application of granulated batch mixtures for the production of titanium-chromium carbide with metallic binders. As the authors demonstrated previously, during the combustion of granulated Ti-C mixtures, the granules retain their size and structural integrity even with the addition of metallic binders. Moreover, granulation of the batch mixture allows one to minimize the influence of the content of gaseous admixtures and humidity of the mixture and ensure the high stability and reproducibility of the produced materials [80,81].

The goal of this work was to investigate the impact of granulation on the SHS of Ti-Cr-C-(Ni/NiCr) mixtures and to optimize the synthesis parameters for the production of uniform and easy-to-grind cermet granules.

\section{Materials and Methods}

The following initial powders were used in this work: PTM grade Ti (supplier: JSC "Polema",

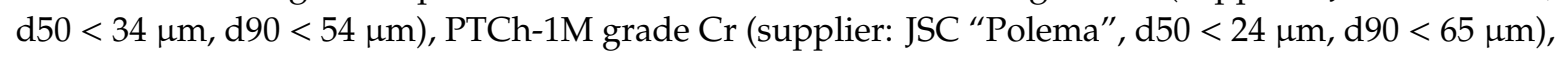


P-803 grade carbon black (supplier: JSC “Ecopolza”, d50 $<2.5 \mu \mathrm{m}$, d90 $<4 \mu \mathrm{m}$ ), NPE-1 grade nickel (supplier: JSC "Mettechinvest", d50 < $100 \mu \mathrm{m}, \mathrm{d} 90<150 \mu \mathrm{m}$ ), Ni-20\%Cr alloy (supplier: JSC "Polema", $\mathrm{d} 50<75 \mu \mathrm{m}, \mathrm{d} 90<142 \mu \mathrm{m}$ ), and Ni-40\%Cr alloy (supplier: JSC "Polema", d50 < $88 \mu \mathrm{m}$, d90< 157 $\mu \mathrm{m})$. Additionally, polyvinyl butyral and $95 \%$ technical alcohol were used.

The composition and nomenclature of the mixtures used in this work are given in Table 1. Granulation of the powder mixtures was performed in the following fashion. The initial powder mixture was prepared for $4 \mathrm{~h}$ in a conventional ball mill ( 60 rotations per minute, 6 liter volume) with the rotational axis shifted for $45^{\circ}$ in the vertical plane. The ball to powder ratio was 6:1. Steel jars and steel milling medium ( $8 \mathrm{~mm}$ balls). The balls and powders filled $40 \%$ of the mill's volume. After the mixing, a $4 \%$ solution of polyvinyl butyral in alcohol was added to the mixture and the obtained paste was rubbed through a mesh with the $1.25 \mathrm{~mm}$ cell size and rounded on a rotating horizontal surface. The granules were then dried during $10 \mathrm{~h}$ and the target fraction of $0.63-1.6 \mathrm{~mm}$ was separated using a vibrating screen.

Table 1. Nomenclature and composition of the used mixtures (M1-M8) and nickel-based binders (B1-B3).

\begin{tabular}{|c|c|c|c|c|c|}
\hline \multirow{2}{*}{ Denotation } & \multirow{2}{*}{ Stoichiometry } & \multicolumn{4}{|c|}{ Elemental Composition (wt.\%) } \\
\hline & & $\mathrm{C}$ & $\mathrm{Cr}$ & $\mathrm{C}$ & $\mathrm{Ni}$ \\
\hline B1 & $\mathrm{Ni}$ & - & - & - & 100.0 \\
\hline B2 & $80 \% \mathrm{Ni} / 20 \% \mathrm{Cr}$ & - & 20.0 & - & 80.0 \\
\hline B3 & $60 \% \mathrm{Ni} / 40 \% \mathrm{Cr}$ & - & 40.0 & - & 60.0 \\
\hline M1 & $70 \%(\mathrm{Ti}+\mathrm{C}) / 30 \%(3 \mathrm{Cr}+2 \mathrm{C})$ & 56.0 & 26.0 & 18.0 & - \\
\hline $\mathrm{M} 2$ & $80 \% \mathrm{M} 1+20 \% \mathrm{~B} 1$ & 44.8 & 20.8 & 14.4 & 20.0 \\
\hline M3 & $80 \% \mathrm{M} 1+20 \% \mathrm{~B} 2$ & 44.8 & 24.4 & 14.4 & 16.0 \\
\hline M4 & $80 \% \mathrm{M} 1+20 \% \mathrm{~B} 3$ & 44.8 & 28.2 & 14.4 & 12.0 \\
\hline M5 & $80 \%(\mathrm{Ti}+\mathrm{C}) / 20 \%(3 \mathrm{Cr}+2 \mathrm{C})$ & 64.0 & 17.2 & 18.8 & - \\
\hline M6 & $80 \% \mathrm{M} 5+20 \% \mathrm{~B} 1$ & 51.2 & 13.8 & 15.0 & 20.0 \\
\hline M7 & $80 \% \mathrm{M} 5+20 \% \mathrm{~B} 2$ & 51.2 & 17.8 & 15.0 & 16.0 \\
\hline M8 & $80 \% \mathrm{M} 5+20 \% \mathrm{~B} 3$ & 51.2 & 21.8 & 15.0 & 12.0 \\
\hline
\end{tabular}

The composition of the initial granulated mixture (M1) and binder (B1) was chosen after the works of Vlasov et al. [80], where the solid solution was synthesized by SHS and then subsequently coated by nickel. The rationale behind the other composition choice has arisen during the investigation.

The features of combustion were investigated using a custom device (Figure 1). The device allows for synthesis in both gas flow and static atmosphere, measurement of gas expenditure and pressure during the combustion, and video recording. Combustion velocity was measured using a video camera with a dark filter. To preclude the geometry creep of the non-combusted part of a specimen during combustion and for overall stabilization of the results, the chamber was washed with Ar before every measurement.

In this work, syntheses were carried out in the argon atmosphere. The microstructure of the combustion products was investigated by scanning electron microscopy (SEM) using the Ultra Plus microscope (Carl Zeiss, Oberkochen, Germany). The phase composition of the combustion products was studied using the DRON-3 diffractometer with the monochromatic $\mathrm{CuK} \alpha$-radiation. Diffraction patterns were recorded in the range $2 \theta=20-80^{\circ}$ with a step of $0.2^{\circ}$ and analyzed by «Crystallographica Search Match» software with Powder Diffraction File database (PDF-2, ICDD, USA, Release 2011). Adiabatic combustion temperature $\left(\mathrm{T}_{\mathrm{ad}}\right)$ was calculated using THERMO software (http://www.ism.ac.ru/thermo/). 


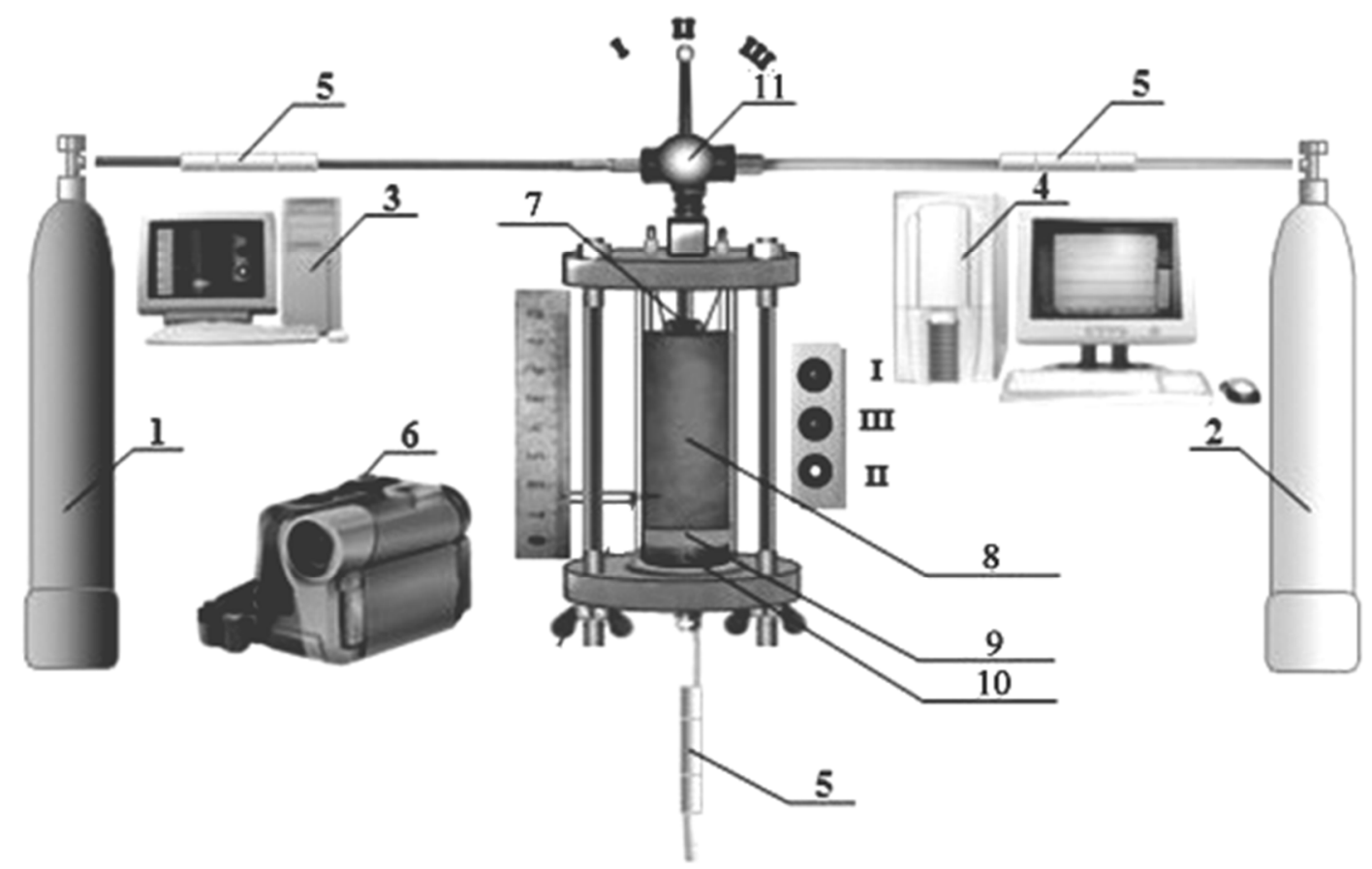

Figure 1. Schematics of the experimental device. 1-nitrogen-filled gas cylinder, 2-Ar-filled gas cylinder, 3-PC for video-recording, 4-PC for the recording of sensor output, 5-sensors for gas expenditure and pressure, 6-digital video camera, 7-electrical spiral, 8-reactive mixture, 9-mineral wool layer, 10—metallic mesh, 11—gas switcher (the position I—nitrogen; II—argon; III—closed).

Gas permeability of powdered and granulated green mixture was measured according to Equation (1). Measurements of the argon flow rate were performed at 1 and $2 \mathrm{~atm}$ difference between the inlet and outlet of installation (Figure 1).

$$
k=\frac{2 P_{1} \mu Q L}{S\left(P_{1}-P_{2}\right)}
$$

where the $\mathrm{k}$ is the gas permeability of the medium (Darcy units), $\mathrm{Q}$ is the volumetric flow rate of gas $\left(\mathrm{cm}^{3} / \mathrm{s}\right)$ at atmospheric pressure, $\mathrm{L}$ is the height of the charge $(\mathrm{cm}), \mathrm{S}$ is the cross-sectional area of the quartz tube $\left(\mathrm{cm}^{2}\right), \mathrm{P}_{1}$ is the gas pressure at the upper end of the sample (atm), $\mathrm{P}_{2}$ is the gas pressure at the lower end of the sample (atm), and $\mu$ is the viscosity of the gas (cP).

\section{Results}

To assess the influence of the granulation process on the combustion velocity and phase composition of the products, the aforementioned SHS installation (Figure 1) was employed to investigate the combustion of powdered and granulated mixtures.

The granulated mixtures demonstrated 1.5 -fold higher combustion velocity as compared with the powdered counterparts (Table 2). For M1 composition, combustion velocity was $22 \mathrm{~mm} / \mathrm{s}$ for granulated mixture and $14 \mathrm{~mm} / \mathrm{s}$ for the powdered mixture. For M2 composition, velocities were 9 and $6 \mathrm{~mm} / \mathrm{s}$ for the granulated and powdered mixtures, correspondingly. The combustion of powdered and granulated M5 and M6 mixtures differed considerably. Granulated mixtures combusted in a stable way, whereas powdered mixtures combusted in a pulsating mode. In the simplest case of steady propagation, all of the wave points move at a constant and identical velocity. When the steadiness is upset, the system may undergo planar autooscillations in the front velocity (pulsating combustion), localization of reaction in one or several hot spots that move along the spiral trajectory (spinning waves), and chaotic motion of numerous hot spots (chaotic solid flames) [82]. 
Table 2. Gas permeability, adiabatic combustion temperature $\left(\mathrm{T}_{\mathrm{ad}}\right)$, measured combustion temperature $\left(\mathrm{T}_{\mathrm{c}}\right)$, and velocity $\left(\mathrm{U}_{\mathrm{c}}\right)$.

\begin{tabular}{|c|c|c|c|c|c|c|c|}
\hline \multirow{2}{*}{ Denotation } & \multicolumn{2}{|c|}{ Gas permeability, Darcy } & \multirow{2}{*}{$\mathrm{T}_{\mathrm{ad}}, \mathrm{K}$} & \multicolumn{2}{|c|}{$\mathrm{T}_{\mathrm{c}}, \mathrm{K}$} & \multicolumn{2}{|c|}{$\mathrm{U}_{\mathrm{c}}, \mathrm{mm} / \mathrm{s}$} \\
\hline & Powdered & Granulated & & Powdered & Granulated & Powdered & Granulated \\
\hline M1 & 2.4 & 24.2 & 2700 & 2240 & 2270 & 14 & 22 \\
\hline M2 & 2.2 & 26.3 & 2350 & 1820 & 1830 & 6 & 9 \\
\hline M3 & 2.8 & 25.7 & 2375 & 1850 & 1840 & 4 & 8 \\
\hline M4 & 3.5 & 27.9 & 2350 & 1860 & 1790 & 5 & 9 \\
\hline M5 & 3.1 & 28.0 & 2950 & 2380 & 2340 & 13 & 24 \\
\hline M6 & 2.8 & 25.2 & 2600 & 2140 & 2150 & 7 & 11 \\
\hline M7 & 2.3 & 26.8 & 2580 & 2120 & 2140 & 6 & 10 \\
\hline M8 & 2.7 & 27.1 & 2575 & 2180 & 2170 & 6 & 12 \\
\hline
\end{tabular}

For purely gas-phase reactions, the reactants are completely intermixed and the measured intrinsic activation energy corresponds to the isolated binary collisions of molecules that lead to a chemical reaction. However, in solid-gas, solid-liquid, and solid-solid reactions, the structural properties have a pronounced effect on the measured kinetic parameters $[82,83]$. The combustion front is usually separated into the pre-heating zone, combustion zone, after-combustion zone, and secondary structure formation zone. In the pre-heating zone, the reactive mixture receives a flux of heat from the nearby combustion front; the heating rate depends mainly on the combustion temperature and thermal conductivity of the reactive mixture. Ignition is usually achieved when the less refractory component melts. In the case of Ti-C mixtures, a Ti-based melt is formed, and the dissolution of carbon in a Ti melt is the main driver of the combustion process [84-86].

The particle size of reactants and the heterogeneity of the system, in general, have a significant influence on the conversion of solid-phase reagents. In a solid reactive mixture, the larger particles create a clear temperature difference between the gas and the surface of the solid reactants, whereas the temperatures of the gas and surface of finer particles are almost identical. The consecutive stages of drying, devolatilization, and combustion of a reactive medium are overlapped for large particles, whereas they are sequential for fine mixtures. This allows for a considerable simplification in the analysis of the combustion of finer reactive mixtures. The propagation of planar combustion waves is usually described in terms of the model of gasless combustion, using the equations of thermal conductivity and chemical kinetics [87]. For example, the recently developed thermochemical model simplifies the combusting process by ignoring the processes occurring on the surface of the combusting particles [88]. In the framework of such models, one could expect that the granulation would decrease the combustion velocity in solid-state reactive mixtures owing to the increased porosity and heterogeneity of the medium. However, our measurements demonstrate a clear increase in the combustion velocity of granulated mixtures.

We suggest that the release of admixture gases during the combustion is a major factor in the combustion front propagation, and the difference of gas permeability between powdered and granulated reactive mixtures is responsible for the difference in combustion velocity. Released gases, filtering through the granulated mixture, convectively heat up and ignite the surface of the reactive granules; the combustion front within individual granules propagates from the surface towards the center. In the powdered mixtures, the convective heating of green mixture by exuding hot gasses is hindered by the formation of viscous melt in the combustion front, which traps the hot gases and prevents the flux of hot gases from the combustion front into the preheating zone. This effect is also responsible for a significant elongation of the samples during combustion [87]. In the granulated mixtures, the melting occurs only within the bounds of individual granules and a network of interconnected open pores is always available, thus allowing for efficient convective heating of reactive granules in the preheating zone. The sources of outgassing are both the residual gaseous impurities in the green powders and the products of decomposition of polyvinyl butyral [89-93]. 
A similar problem was previously addressed in the area of the combustion of solid fuels. Some of the results indeed indicate that the larger fuel particles attain a higher propagation rate. The increase of fuel density was not associated with lower specific reactant conversion rates or significant changes in the structure of the combustion front [94]. To support this hypothesis, gas permeability was measured for the powdered and granulated mixtures of all compositions. The values can be found in Table 2 along with the calculated adiabatic combustion temperatures and measured combustion temperatures and velocities. The granulation was associated with a nearly 10 -fold increase in gas permeability (from 2-3 to 25-28 Darcy).

For the composition without the metallic binder (M1, M5), X-Ray diffraction (XRD) of the combustion products did not reveal any differences for the powder and granulated mixtures. The calculated phases at combustion temperature and experimentally defined phase composition are provided in Table 3.

Table 3. The calculated and measured phase composition.

\begin{tabular}{|c|c|c|}
\hline Mixture & $\begin{array}{l}\text { Phase composition at } T_{a d} \\
\text { Calculated by Thermo }\end{array}$ & $\begin{array}{c}\text { The Phase Composition of } \\
\text { Combustion Products }\end{array}$ \\
\hline M1 & $\mathrm{TiC}, \mathrm{Cr}_{3} \mathrm{C}_{2}$ & $(\mathrm{Ti}, \mathrm{Cr}) \mathrm{C}, \mathrm{TiC}$ \\
\hline M2 & $\mathrm{TiC}, \mathrm{Ni}_{(\mathrm{liq})}, \mathrm{Cr}_{3} \mathrm{C}_{2}, \mathrm{Cr}_{7} \mathrm{C}_{3}$ (minor) & $(\mathrm{Ti}, \mathrm{Cr}) \mathrm{C}, \mathrm{Ni}_{2.88} \mathrm{Cr}_{1.12}, \mathrm{Cr}_{3} \mathrm{C}_{2}$, \\
\hline M3 & $\mathrm{TiC}, \mathrm{Ni}, \mathrm{Cr}_{7} \mathrm{C}_{3}, \mathrm{Cr}_{3} \mathrm{C}_{2}$ & $(\mathrm{Ti}, \mathrm{Cr}) \mathrm{C}, \mathrm{Ni}_{2.88} \mathrm{Cr}_{1.12}, \mathrm{Cr}_{3} \mathrm{C}_{2}$, \\
\hline M4 & $\mathrm{TiC}, \mathrm{Ni}, \mathrm{Cr}_{7} \mathrm{C}_{3}, \mathrm{Cr}_{3} \mathrm{C}_{2}$ & $(\mathrm{Ti}, \mathrm{Cr}) \mathrm{C}, \mathrm{Ni}_{2.88} \mathrm{Cr}_{1.12}, \mathrm{Cr}_{7} \mathrm{C}_{3}$, \\
\hline M5 & $\mathrm{TiC}, \mathrm{Cr}_{3} \mathrm{C}_{2}, \mathrm{C}$ (minor) & $(\mathrm{Ti}, \mathrm{Cr}) \mathrm{C}$ \\
\hline M6 & $\mathrm{TiC}, \mathrm{Ni}_{(\mathrm{liq})}, \mathrm{Cr}_{3} \mathrm{C}_{2}, \mathrm{C}$ (minor) & $(\mathrm{Ti}, \mathrm{Cr}) \mathrm{C}, \mathrm{Ni}_{2.88} \mathrm{Cr}_{1.12}$ \\
\hline M7 & $\mathrm{TiC}, \mathrm{Ni}_{(\mathrm{liq})}, \mathrm{Cr}_{3} \mathrm{C}_{2}, \mathrm{Cr}_{7} \mathrm{C}_{3}$ & $(\mathrm{Ti}, \mathrm{Cr}) \mathrm{C}, \mathrm{Ni}_{2.88} \mathrm{Cr}_{1.12}, \mathrm{Cr}_{3} \mathrm{C}_{2}$, \\
\hline M8 & $\mathrm{TiC}, \mathrm{Ni}_{(\mathrm{liq})}, \mathrm{Cr}_{7} \mathrm{C}_{3}, \mathrm{Cr}_{3} \mathrm{C}_{2}$ & $(\mathrm{Ti}, \mathrm{Cr}) \mathrm{C}, \mathrm{Ni}_{2.88} \mathrm{Cr}_{1.12}, \mathrm{Cr}_{3} \mathrm{C}_{2}$, \\
\hline
\end{tabular}

The difference in the phase composition of combustion products at $\mathrm{T}_{\mathrm{ad}}$ calculated by Thermo and investigated by XRD at room temperature (Table 3) originates from the lack of thermodynamic data on carbide solid solutions. For all four-component mixtures (M2-M4, M6-M8), the diffusion of chromium into the TiC-based solid solution leads to the decomposition of the $\mathrm{Cr}$-rich $\mathrm{Cr}_{7} \mathrm{C}_{3}$ phase and formation of $\mathrm{Cr}$-poor $\mathrm{Ni}_{2.88} \mathrm{Cr}_{1.12}$.

This process produces a prolonged fluorescence of combustion products. The analysis of videotapes of the combustion process revealed 8 to $14 \mathrm{~s}$ long fluorescence of the combustion products produced from NiCr-containing mixtures (Figure 2). No differences were observed in the phase composition of products of combustion of the powdered and granulated mixtures. 

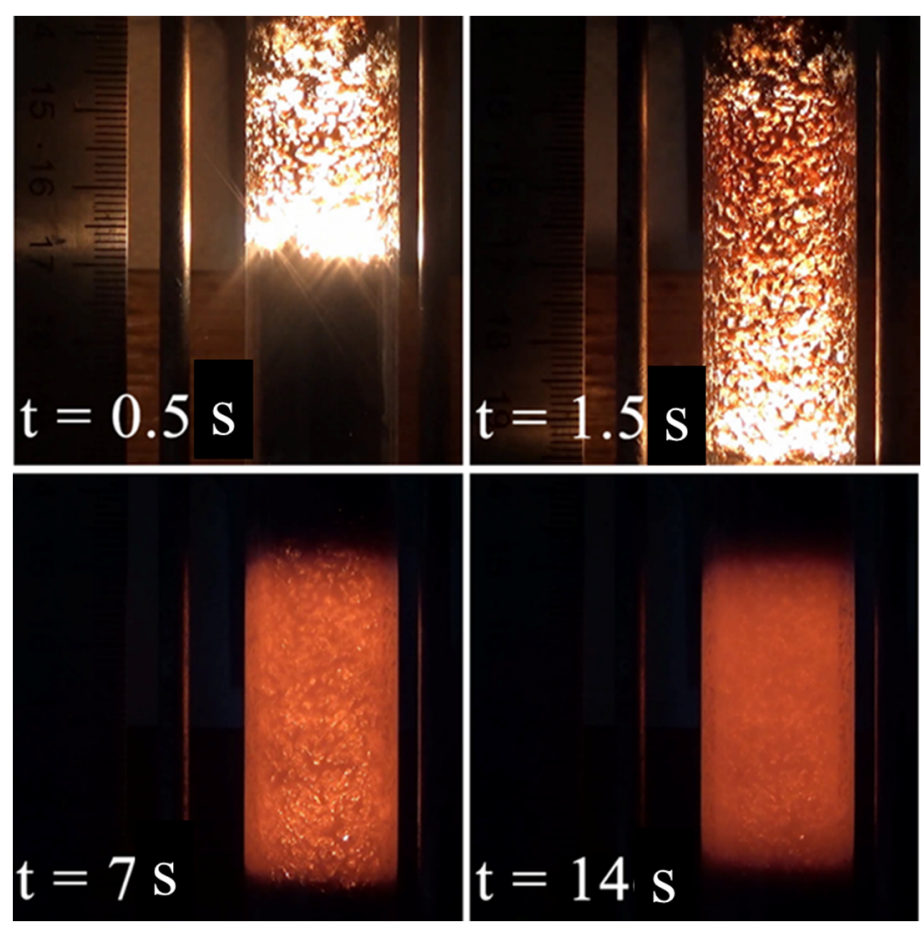

Figure 2. Frames from the videotape of the combustion of granulated M5 mixture (time is counted from the ignition).

The fluorescence is presumably related to the exothermic secondary phase formation in the after-combustion zone, which is corroborated by the lack of a prolonged fluorescence and faster cooling of a specimen prepared from the granulated $\mathrm{Ti}+\mathrm{C}$ mixture, although the combustion temperature for this mixture is higher than for Ti-Cr-C. One should note that the specimens without the metallic binder (M1, M5) featured the presence of $\mathrm{TiC}$ in addition to (Ti, Cr)C (Figure 3a), but TiC was absent in the combustion products produced in semi-industrial SHS reactor from M1 mixture (Figure 4a).

The difference in the phase composition of products obtained under different conditions can be explained if we take into account the sequence of the chemical conversion process and the difference in the product cooling rate. The mass of the initial mixture is almost 100 times higher in the semi-industrial SHS reactor as compared with the lab reactor. Therefore, the cooling rate is degrees of magnitude lower, which provides sufficient time for diffusion processes to be completed. In the framework of this mechanism, the presence of $\mathrm{TiC}$ in the small-volume combustion products is inevitable, as it is the most refractory compound (Tmelt $=3200 \mathrm{~K}$ ) among the intermediate combustion products. These samples cool down faster than the formation of the $(\mathrm{Ti}, \mathrm{Cr}) \mathrm{C}$ phase is concluded.

Let us discuss the influence of metallic binder content on the composition of synthesis products produced from the granulated mixtures. XRD of combustion products of the M1 mixture revealed the formation of the (Ti,Cr)C solid solution with a minor amount of TiC (Figure 3a). An addition of 20 w. $\%$ nickel binder (mixture M2) alters the phase composition (Figure $3 b$ ) and leads to the formation of chromium carbide and nickel-chromium intermetallic. Zhang et al. [77] showed that peaks of the main phase $(\mathrm{Ti}, \mathrm{Cr}) \mathrm{C}$ shift towards the lower angles, signifying the decrease of chromium content in $(\mathrm{Ti}, \mathrm{Cr}) \mathrm{C}$. This shift of $(\mathrm{Ti}, \mathrm{Cr}) \mathrm{C}$ peak is demonstrated in Figure 3 for compositions with the various content. XRD has also revealed that part of the $\mathrm{Cr}$ has bonded with the $\mathrm{Ni}$ as the nichrome phase has emerged in the pattern. 


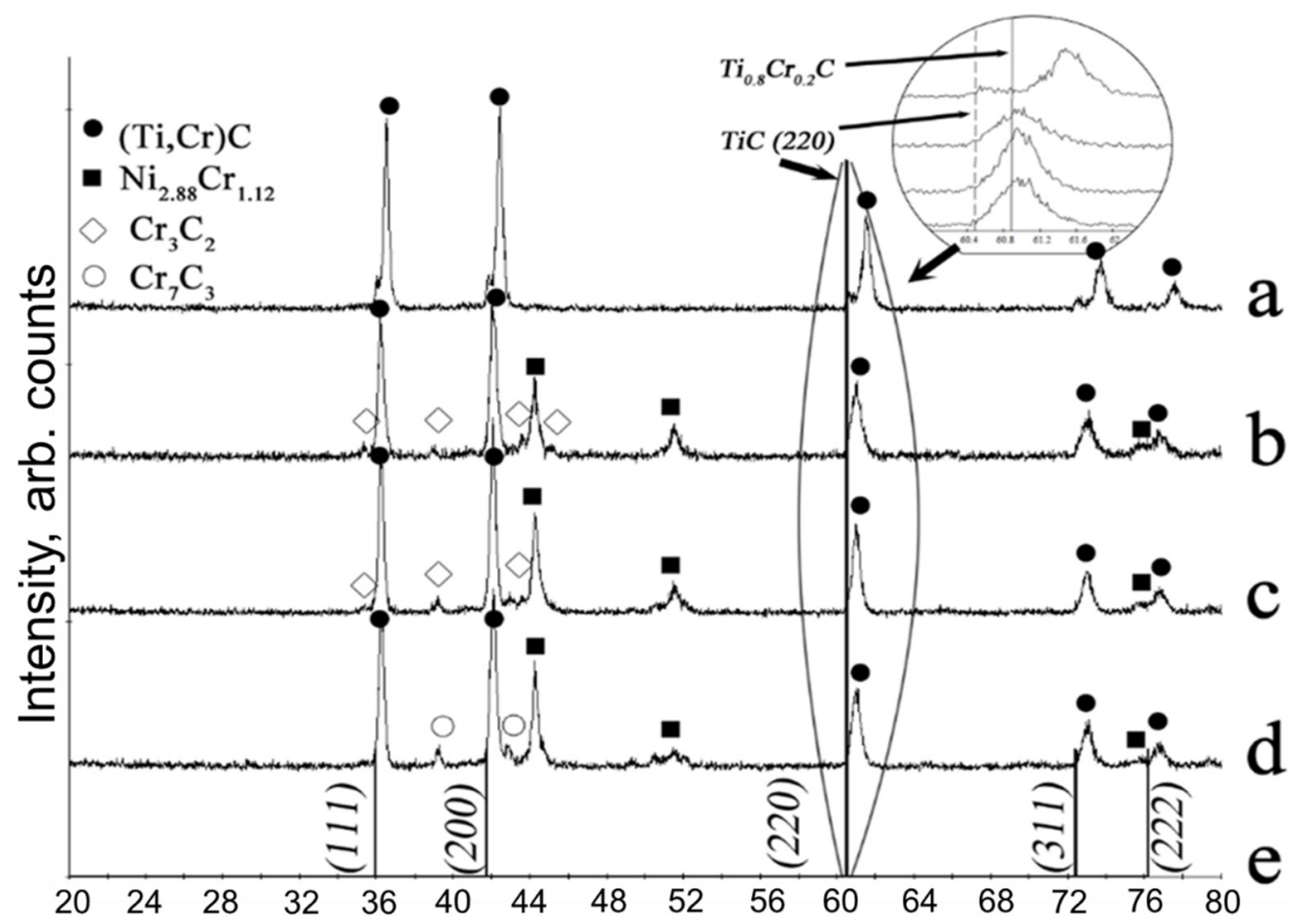

Figure 3. XRD patterns for the combustion products from granulated mixtures with various compositions of the metallic binder: (a)-M1, (b)-M2, (c)—M3, (d)—M4 (see Table 1); e—etalon TiC lines. Circle highlights the shift of one of the $(\mathrm{Ti}, \mathrm{Cr}) \mathrm{C}$ peaks.

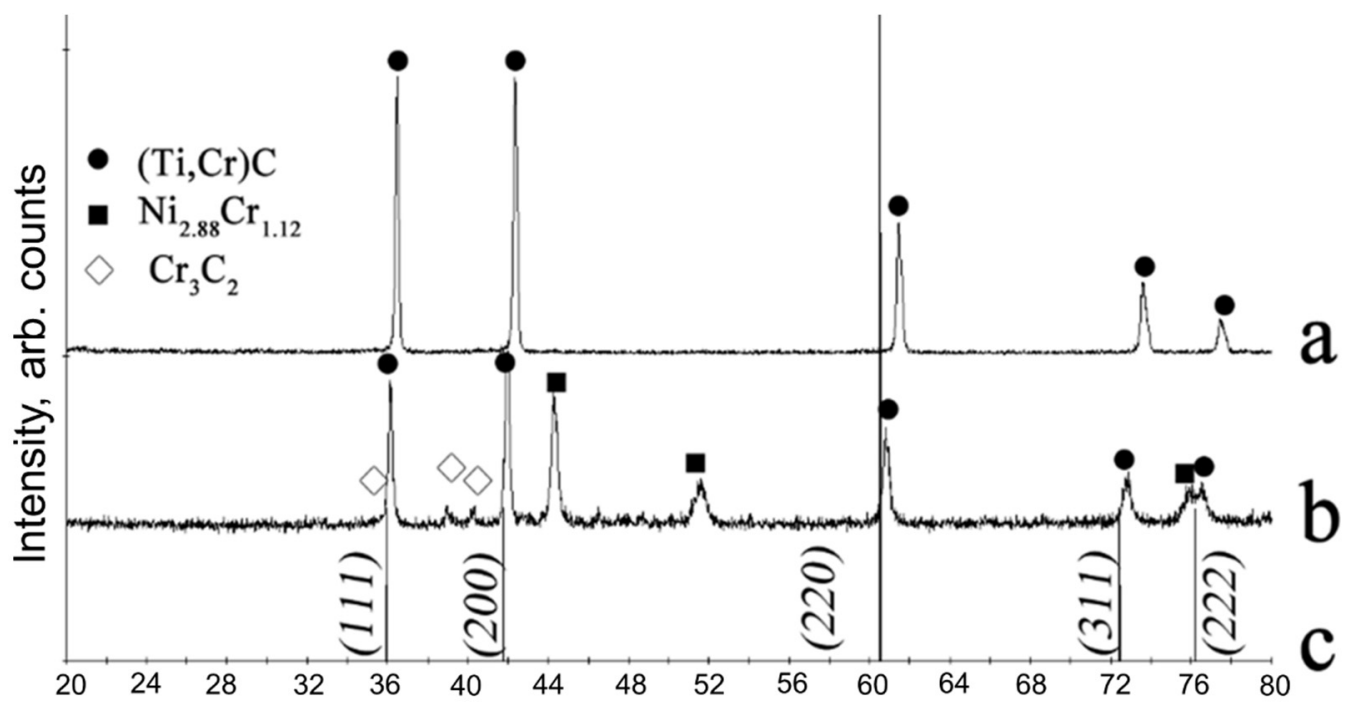

Figure 4. XRD pattern for products synthesized from powdered mixtures in semi-industrial self-propagating high-temperature synthesis (SHS) reactor: (a) M1 and (b) M2 (see Table 1). (c) shows the etalon $\mathrm{TiC}$ lines.

To investigate the influence of scale factor on the phase composition of the combustion products, we compared the XRD data from our specimens (Figure 3) with the specimens produced in a semi-industrial SHS reactor (Figure 4). In the SHS reactor, Vlasov et al. [79] synthesized M1 and M2 mixtures, herewith, the reactor load was $12 \mathrm{~kg}$. As compared with the specimens produced using the lab reactor (Figure 3a), the specimens from the semi-industrial reactor (Figure $4 \mathrm{a}$ ) do not contain the TiC phase. The addition of $20 \mathrm{wt.} \%$ of nickel into the mixture altered the composition of the products obtained from the semi-industrial SHS reactor (Figure $4 \mathrm{~b}$ ) and caused the formation of chromium carbide and nichrome, the same as in Figure 3b. Therefore, the change of phase composition upon the introduction of nickel 
binder does not pertain to the sample's geometry, but rather to the changes of the combustion and phase formation mechanisms.

Zhang et al. [78] suggested that the decreased content of $\mathrm{Cr}$ in solid solution (Ti,Cr)C is related to the decreased combustion temperature of reactive mixturex. Indeed, addition of $20 \mathrm{wt} . \% \mathrm{Ni}$ decreases the adiabatic combustion temperature $\mathrm{T}_{\mathrm{ad}}$ from $2700 \mathrm{~K}$ (M1 composition) to $2350 \mathrm{~K}$ (M2 composition). The decrease of Tad lowers the combustion velocity from $22 \mathrm{~mm} / \mathrm{s}$ to $9 \mathrm{~mm} / \mathrm{s}$. To increase the $\mathrm{Cr}$ content in $(\mathrm{Ti}, \mathrm{Cr}) \mathrm{C}$ and eliminate the chromium carbide phases, we have to increase the combustion temperature. This could be attained by increasing the content of $\mathrm{Ti}+\mathrm{C}$ fraction in the mixture, for example, to M5 composition. For this composition, $\mathrm{T}_{\mathrm{ad}}$ is equal to $2950 \mathrm{~K}$. An addition of $20 \mathrm{wt} . \%$ $\mathrm{Ni}$ binder (composition M6) leads to a decrease of $\mathrm{T}_{\mathrm{ad}}$ down to $2600 \mathrm{~K}$, which is close to $\mathrm{T}_{\mathrm{ad}}$ for M1 composition. The combustion velocities of granulated compositions M5 and M6 increased to 35 and $16.5 \mathrm{~mm} / \mathrm{s}$, correspondingly. According to the XRD data, M5 combustion products contain $(\mathrm{Ti}, \mathrm{Cr}) \mathrm{C}$ with a small amount of TiC. Upon the addition of nickel (M6 composition), the content of $\mathrm{Cr}$ in TiC decreases drastically, in the same manner as in the composition M2. The peak of solid solution shifts to the left and is close to the pure TiC peak (Figure $5 a, b)$. No direct dependencies between combustion temperature and $\mathrm{Cr}$ content in solid solutions were found in mixtures with a nickel binder.

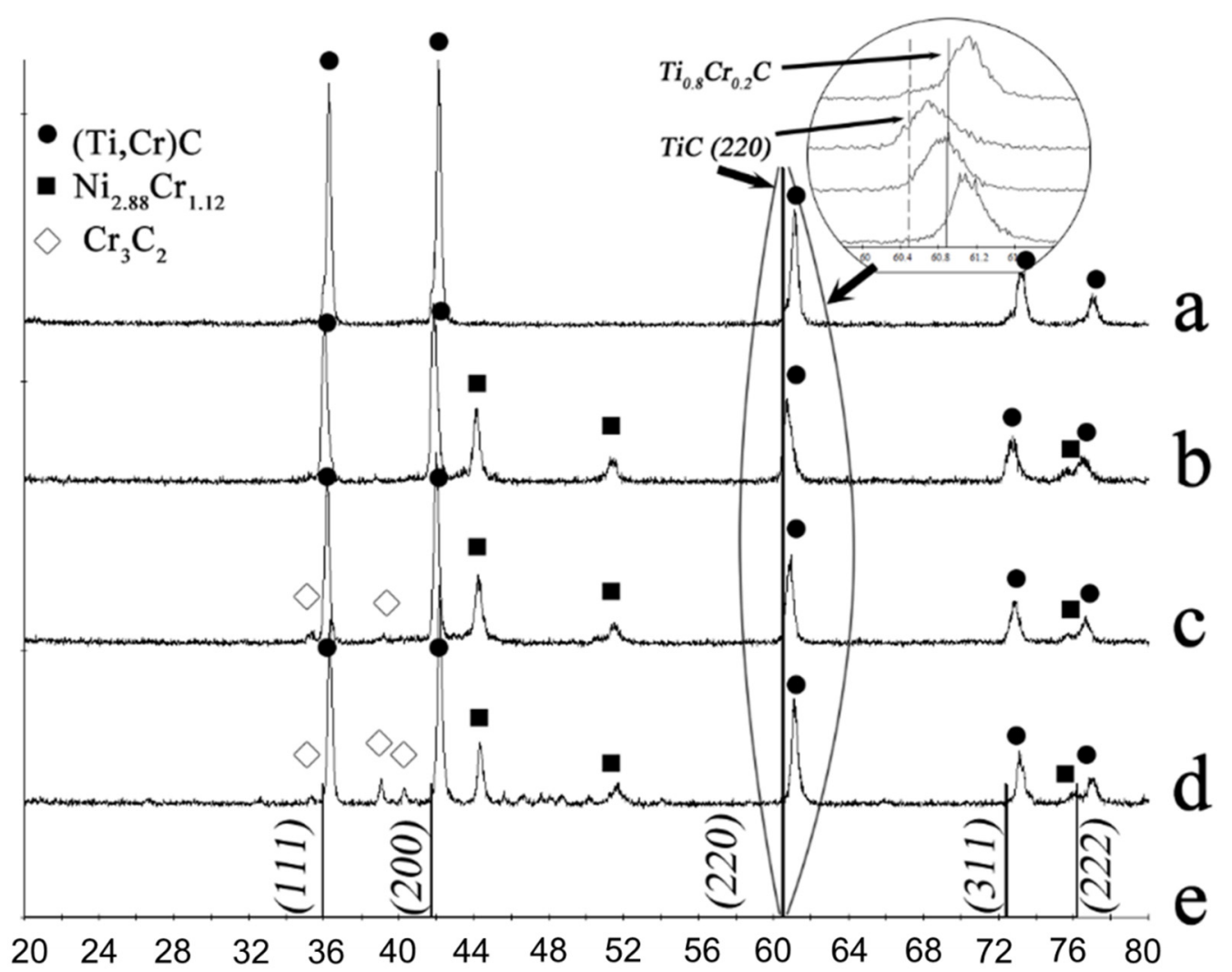

Figure 5. XRD patterns for the combustion products of granulated $80 \%(\mathrm{Ti}+\mathrm{C}) / 20 \%(3 \mathrm{Cr}+2 \mathrm{C})$ mixture with various binder compositions: (a-no binder, (b) $-20 \% \mathrm{Ni},(\mathbf{c})-20 \% \mathrm{NiCr}(80 \% \mathrm{Ni} / 20 \% \mathrm{Cr})$, (d) $-20 \% \mathrm{NiCr}(60 \% \mathrm{Ni} / 40 \% \mathrm{Cr})$. (e) provides etalon $\mathrm{TiC}$ lines. The circle denotes the shift of one of the (Ti,Cr)C peaks.

The addition of $20 \mathrm{wt} . \% \mathrm{Ni}$ as the binder leads to the formation of the $\mathrm{Ni}_{2.88} \mathrm{Cr}_{1.12}$ phase. Therefore, chromium must be (partly) forming a solid solution with nickel, as $\mathrm{Cr}$ and $\mathrm{Ni}$ are well-soluble in each other [81]. Apparently, Ni, which has a lower melting temperature, melts first and spreads on $\mathrm{Cr}$ particles with the formation of nichrome, which immobilizes $\mathrm{Cr}$ and prevents the formation of (Ti, $\mathrm{Cr}) \mathrm{C}$ with the calculated composition. To prevent $\mathrm{Cr}$ depletion owing to the formation of nichrome, the following experiments were conducted with $\mathrm{Ni}$ replaced by the $\mathrm{Ni}-20 \% \mathrm{Cr}$ and $\mathrm{Ni}-40 \% \mathrm{Cr}$ alloys 
(binders B2, B3 in Table 1). XRD data for combustion products of compositions M3, M4, M7, and M8 are provided in Figure 3c,d and Figure $5 c, d$.

Figure 3 demonstrates that the substitution of nickel with nichrome did not lead to the increase of $\mathrm{Cr}$ content in $(\mathrm{Ti}, \mathrm{Cr}) \mathrm{C}$, that is, to the shift of the solid solution peak towards the larger angles (see the (220) peak in the magnified fragment of XRD pattern in Figure 3). When the nichrome (Ni-40\%Cr) alloy was used, chromium carbides and $\mathrm{Cr}_{7} \mathrm{Ni}_{3}$ solid solution were formed, signifying the excess of $\mathrm{Cr}$ in the initial mixture. However, for composition M7, the substitution of Ni to nichrome $(20 \% \mathrm{Cr})$ leads to the increased content of $\mathrm{Cr}$ in $(\mathrm{Ti}, \mathrm{Cr}) \mathrm{C}$ and little to no unwanted by-product phases (Figure 5c). For M8 composition (binder with $40 \% \mathrm{Cr}$ ), unwanted $\mathrm{Cr}$-based solid solutions and chromium carbides are formed (Figure $5 \mathrm{~d}$ ).

It is noteworthy that synthesis products produced from all of the investigated granulated mixtures, both with and without the metallic binder, were in a form of brittle sinter cake comprised of granules with the same size as in the initial mixture. Figure 6 demonstrated the porous, easy-to-grind granules of combustion products.

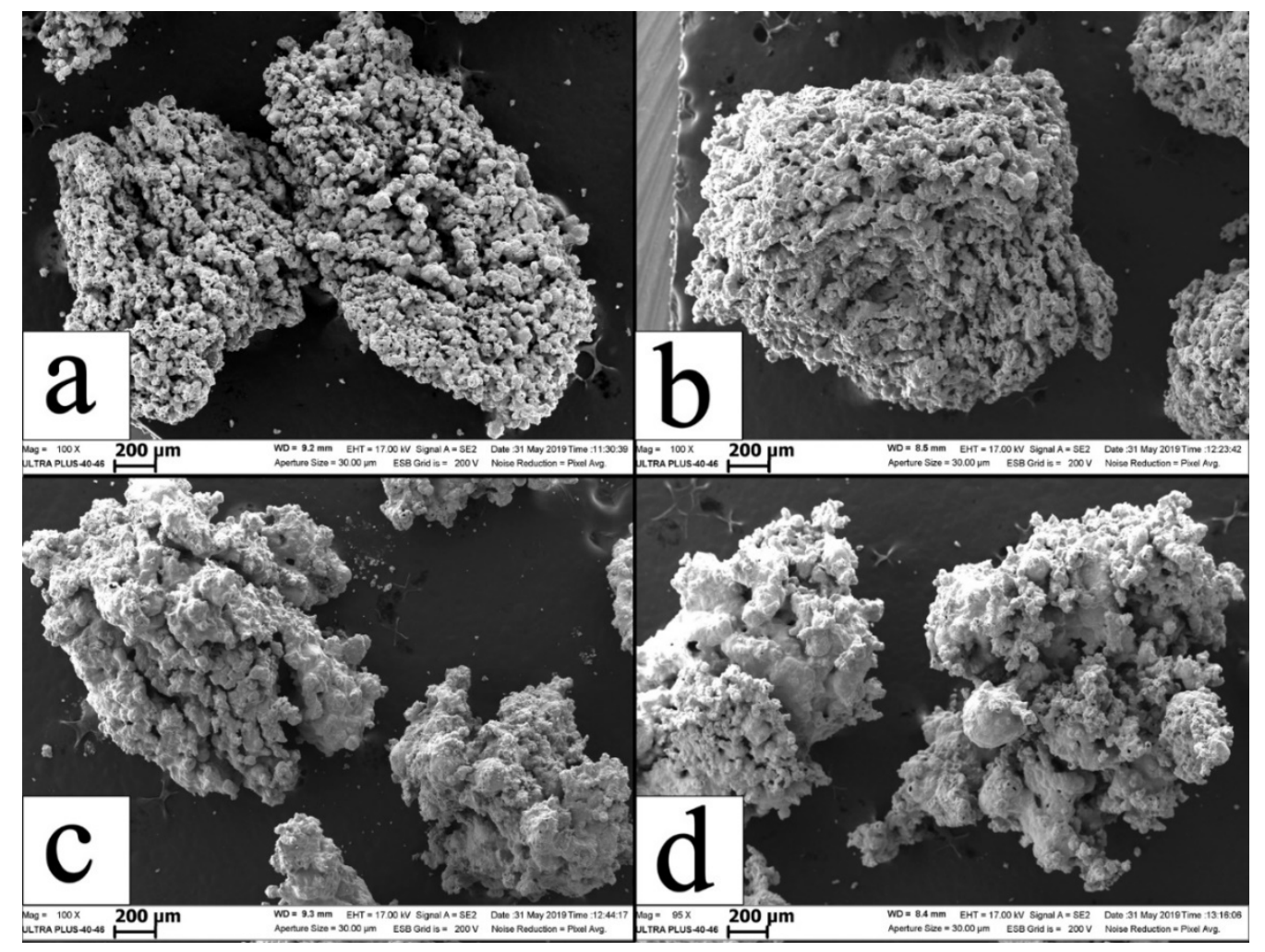

Figure 6. SEM images of combustion products from granulated mixtures M1 (a), M5 (b), M3 (c), M7 (d).

Porosity arises from the emission of adsorbed gases and products of decomposition of polyvinyl butyral, which arrests the coagulation of droplets formed during combustion. The fractures of individual granules of combustion products are provided in Figure 7. Noticeably, all SEM images demonstrate that the grains of combustion products are $2-5 \mu \mathrm{m}$, which is an order of magnitude below the size of $\mathrm{Cr}$ and $\mathrm{Ti}$ particles owing to the self-dispersion of starting reagents during the combustion. 


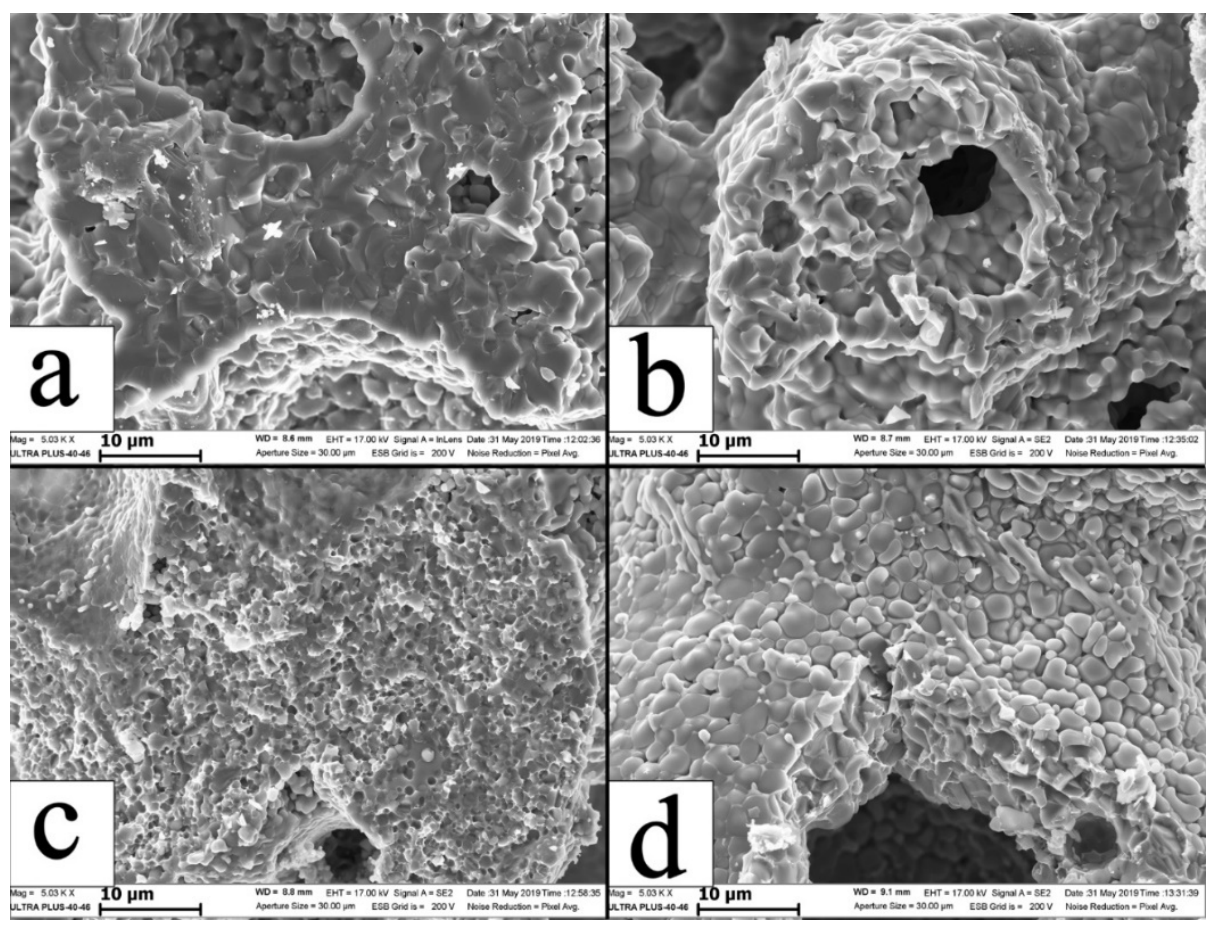

Figure 7. The microstructure of individual granules of combustion products from mixtures M1 (a), M5 (b), M3 (c), and M7 (d).

Combustion products of granulated specimens with the metallic binder could be crushed into $<1$ $\mu \mathrm{m}$ powder both in a mortar and using the hydraulic press at approximately $2.45 \mathrm{MPa}$ (Figure 8b). Combustion products from non-granulated mixtures could be ground only if they contained no metallic binder. Binder-containing non-granulated samples could be crushed to the 5-10 $\mathrm{mm}$ pieces using the hydraulic press at $2.45 \mathrm{MPa}$ pressure (Figure $8 \mathrm{~d}$ ) and then to $1-2 \mathrm{~mm}$ pieces using $12.25 \mathrm{MPa}$ pressure (Figure 8e).

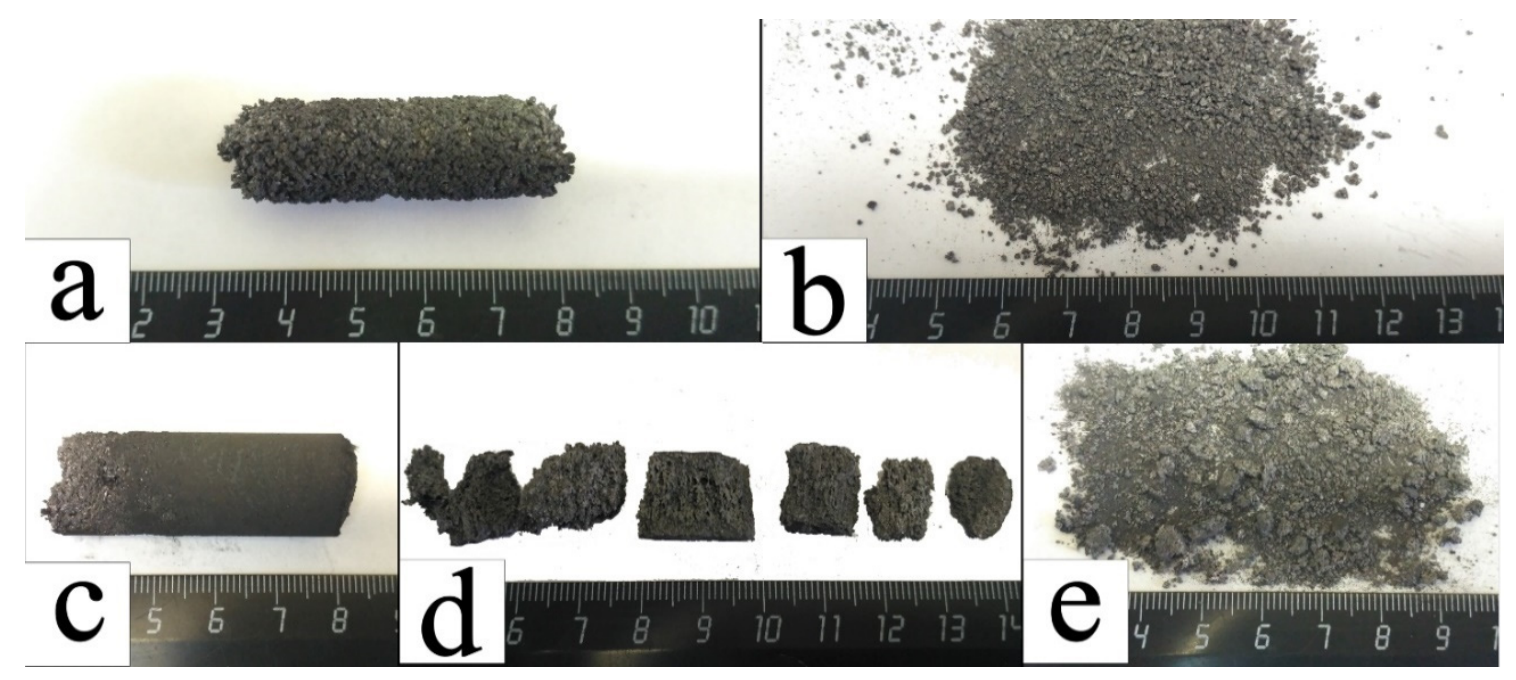

Figure 8. Combusted products of mixture M6: specimen synthesized from the granulated mixture (a); sample (a) crushed using 2.45 MPa pressure (b); specimen synthesized from powder mixture (c); specimen (c) after crushing using 2.45 MPa pressure (d); specimen (c) crushed using $12.25 \mathrm{MPa}$ pressure (e).

Thus, in this work, we used SHS of granulated $80 \%(\mathrm{Ti}+\mathrm{C}) / 20 \%(3 \mathrm{Cr}+2 \mathrm{C})$ mixture with a nichrome $(\mathrm{Ni}-20 \% \mathrm{Cr})$ binder to produce in one technologic operation the $(\mathrm{Ti}, \mathrm{Cr}) \mathrm{C}$ solid solution with 
nickel-containing binder and a minor amount of impurities. Products of combustion of agglomerated mixtures could be crushed and ground easily. This suggests a perspective of the application of granulation of reactive mixtures for the SHS of composite powders with an optimal combination of melting point, hardness, corrosion, and ablation resistance for various applications, including the flame spraying [95-98].

\section{Conclusions}

1. The granulation of reactive mixtures $\mathrm{Ti}+\mathrm{C}, 70 \%(\mathrm{Ti}+\mathrm{C}) / 30 \%(3 \mathrm{Cr}+2 \mathrm{C})$, and $80 \%(\mathrm{Ti}+$ $\mathrm{C}) / 20 \%(3 \mathrm{Cr}+2 \mathrm{C})$ was demonstrated to increase the combustion velocity by 1.5 -fold; the granules in the combustion products retained their size and did not sinter.;

2. The compositions with metallic binder featured a prolonged fluorescence after the passing of the combustion front, presumably owing to the occurrence of exothermic secondary phase formation processes;

3. The addition of nickel decreases the $\mathrm{Cr}$ content in $(\mathrm{Ti}, \mathrm{Cr}) \mathrm{C}$ solid solution owing to the interaction of nickel melt with chromium and formation of $\mathrm{NiCr}$ intermetallic;

4. For the granulated $80 \%(\mathrm{Ti}+\mathrm{C}) / 20 \%(3 \mathrm{Cr}+2 \mathrm{C})$ mixture, the substitution of $\mathrm{Ni}$ to $\mathrm{Ni}-20 \% \mathrm{Cr}$ and $\mathrm{Ni}-30 \% \mathrm{Cr}$ alloys resulted in the increase of $\mathrm{Cr}$ content in solid solution and the formation of $(\mathrm{Ti}, \mathrm{Cr}) \mathrm{C}$ with NiCr binder;

5. Combustion products procured from granulated mixtures could be more easily processed into powders owing to the decreased ductility of the combustion products.

Author Contributions: Conceptualization, S.V. and B.S.S.; methodology, B.S.S.; software, R.A.K.; validation, N.I.A.; formal analysis, I.D.K.; investigation, B.S.S. and R.A.K.; resources, B.S.S.; data curation, P.V.K.-K.; writing-original draft preparation, S.V. and B.S.S.; writing-review and editing, S.V. and P.V.K.-K.; visualization, T.G.L.; supervision, A.A.Z.; project administration, B.S.S.; funding acquisition, B.S.S. All authors have read and agreed to the published version of the manuscript.

Funding: This research received no external funding.

Acknowledgments: Authors are grateful to V.V. Zakorjevsky for providing the specimens synthesized in semi-industrial SHS reactor.

Conflicts of Interest: The authors declare no conflict of interest.

\section{References}

1. Cordoba, J.M.; Chicardi, E.; Gotor, F.J. Liquid-phase sintering of Ti (C, N)-based cermets. The effects of binder nature and content on the solubility and wettability of hard ceramic phases. J. Alloys Compd. 2013, 559, 34-38. [CrossRef]

2. Sahoo, P.; Davim, J.P. Tribology of Ceramics and Ceramic Matrix Composites. In Tribology for Scientists and Engineers; Springer: New York, NY, USA, 2013; pp. 211-231.

3. Caccia, M.; Tabandeh-Khorshid, M.; Itskos, G.; Strayer, A.R.; Caldwell, A.S.; Pidaparti, S.; Singnisai, S.; Rohskopf, A.D.; Schroeder, A.M.; Jarrahbashi, D.; et al. Ceramic-metal composites for heat exchangers in concentrated solar power plants. Nature 2018, 562, 406-409. [CrossRef] [PubMed]

4. Rajabi, A.; Ghazali, M.; Junaidi, S.; Daud, A. Development and application of tool wear: A review of the characterization of tic-based cermets with different binders. Chem. Eng. J. 2014, 255, 445-452. [CrossRef]

5. Guo, X.; Yang, H.; Zhu, X.; Zhang, L. Preparation and properties of nano-SiC-based ceramic composites containing nano-TiN. Scr. Mater. 2013, 68, 281-284. [CrossRef]

6. Aslantas, K.; Ucun, I.; Cicek, A. Tool life and wear mechanism of coated and uncoated $\mathrm{Al}_{2} \mathrm{O}_{3} / \mathrm{TiCN}$ mixed ceramic tools in turning hardened alloy steel. Wear 2012, 274, 442-451. [CrossRef]

7. Singh, P.; Singh, B.; Kumar, M.; Kumar, A. One step reduction of boric acid to boron carbide nano particles. Ceram. Int. 2014, 40, 15331-15334. [CrossRef]

8. Toth, L. Transition Metal Carbides and Nitrides; Elsevier: Amsterdam, The Netherlands, 2014.

9. Funamori, N.; Sato, T. A cubic boron nitride gasket for diamond-anvil experiments. Rev. Sci. Instrum. 2008, 79, 053903. [CrossRef] 
10. Muguthu, J.N.; Gao, D. Profile fractal dimension and dimensional accuracy analysis in machining metal matrix composites (MMCs). Mater. Manuf. Process. 2013, 28, 1102-1109. [CrossRef]

11. Abderrazak, H.; Schoenstein, F.; Abdellaoui, M.; Jouini, N. Spark plasma sintering consolidation of nanostructured TiC prepared by mechanical alloying. Int. J. Refract. Met. Hard Mater. 2011, 29, 170-176. [CrossRef]

12. Razavi, M.; Rajabi-Zamani, A.H.; Rahimipour, M.R.; Kaboli, R.; Shabani, M.O.; Yazdani-Rad, R. Synthesis of $\mathrm{Fe}-\mathrm{TiC}-\mathrm{Al}_{2} \mathrm{O}_{3}$ hybrid nanocomposite via carbothermal reduction enhanced by mechanical activation. Ceram. Int. 2011, 37, 443-449. [CrossRef]

13. Wei, S.; Xu, B.Q.; Bin, Y.; Sun, H.Y.; Song, J.X.; Wan, H.L.; Dai, Y.N. Preparation of TiC powders by carbothermal reduction method in vacuum. Trans. Nonferrous Met. Soc. China 2011, 21, 185-190.

14. Kang, Y.; Kang, S. WC-reinforced (Ti,W)(CN). J. Eur. Ceram. Soc. 2010, 30, 793-798. [CrossRef]

15. Zhang, H.; Li, F.; Jia, Q.; Ye, G. Preparation of titanium carbide powders by sol-gel and microwave carbothermal reduction methods at low temperature. J. Sol-Gel Sci. Technol. 2008, 46, 217-222. [CrossRef]

16. Li, Y.; Liu, N.; Zhang, X.; Rong, C. Effect of WC content on the microstructure and mechanical properties of $(\mathrm{Ti}, \mathrm{W})(\mathrm{C}, \mathrm{N})-\mathrm{Co}$ cermets. Int. J. Refract. Met. Hard Mater. 2008, 26, 33-40. [CrossRef]

17. Wu, Y.; Xiong, J.; Guo, Z.; Yang, M.; Chen, J.; Xiong, S.; Fan, H.; Luo, J. Microstructure and fracture toughness of $\mathrm{Ti}\left(\mathrm{C}_{0.7} \mathrm{~N}_{0.3}\right)$-WC-Ni cermets. Int. J. Refract. Met. Hard Mater. 2011, 29, 85-89. [CrossRef]

18. Zheng, Y.; Wang, S.; You, M.; Tan, H.; Xiong, W. Fabrication of nanocomposite Ti (C, N)-based cermet by spark plasma sintering. Mater. Chem. Phys. 2005, 92, 64-70. [CrossRef]

19. Shi, X.; Wang, M.; Xu, Z.; Zhai, W.; Zhang, Q. Tribological behavior of $\mathrm{Ti}_{3} \mathrm{SiC}_{2} /(\mathrm{WC}-10 \mathrm{Co})$ composites prepared by spark plasma sintering. Mater. Des. 2013, 45, 365-376. [CrossRef]

20. Klaasen, H.; Kübarsepp, J.; Sergejev, F. Strength and failure of TiC based cermets. Powder Metall. 2009, 52, 111-115. [CrossRef]

21. Compton, B.; Zok, F. Impact resistance of TiC-based cermets. Int. J. Impact Eng. 2013, 62, 75-87. [CrossRef]

22. Stewart, T.L.; Plucknett, K.P. The sliding wear of TiC and Ti (C, N) cermets prepared with a stoichiometric $\mathrm{Ni}_{3} \mathrm{Al}$ binder. Wear 2014, 218, 153-167. [CrossRef]

23. Bhaskar, U.K.; Pradhan, S. One-step mechanosynthesis of nano structured Ti (CxN1-x) cermets at room temperature and their microstructure characterization. Mater. Chem. Phys. 2012, 134, 1088-1096. [CrossRef]

24. Liang, M.; Xiong, J.; Guo, Z.; Wan, W.; Dong, G. The influence of TiN content on erosion- corrosion behavior of Ti (C, N)-based cermets. Int. J. Refract. Met. Hard Mater. 2013, 41, 210-215. [CrossRef]

25. Liu, N.; Xu, Y.; Li, Z.; Chen, M.; Li, G.; Zhang, L. Influence of molybdenum addition on the microstructure and mechanical properties of TiC-based cermets with nano-TiN modification. Ceram. Int. 2003, 29, 919-925. [CrossRef]

26. Maweja, K.; Cornish, L.; Can, N. Annealing behaviour of sub-stoichiometric Ti (C, N)-W mechanical alloy powders. Int. J. Refract. Met. Hard Mater. 2011, 29, 445-451. [CrossRef]

27. Han, C.; Kong, M. Fabrication and properties of TiC-based cermet with intra/intergranular microstructure. Mater. Des. 2009, 30, 1205-1208. [CrossRef]

28. Li, Y.; Liu, N.; Li, Y. Carbon nanotube/ultrafine grade Ti (C, N) based cermets composite. Mater. Sci. Technol. 2011, 27, 1287-1293. [CrossRef]

29. Seo, M.; Kim, J.; Kang, S. Effect of carbon content on the microstructure and properties of $\left(\mathrm{Ti}_{0.7} \mathrm{~W}_{0.3}\right) \mathrm{C}-\mathrm{Ni}$ cermet. Int. J. Refract. Met. Hard Mater. 2011, 29, 424-428. [CrossRef]

30. Aykut, S.; Bagci, E.; Kentli, A.; Yazıcıoğlu, O. Experimental observation of tool wear, cutting forces and chip morphology in face milling of cobalt based super-alloy with physical vapour deposition coated and uncoated tool. Mater. Des. 2007, 28, 1880-1888. [CrossRef]

31. Ettmayer, P.; Kolaska, H.; Lengauer, W.; Dreyer, K. Ti (C, N) cermets-Metallurgy and properties. Int. J. Refract. Met. Hard Mater. 1995, 13, 343-351. [CrossRef]

32. Chen, L.; Lengauer, W.; Dreyer, K. Advances in modern nitrogen-containing hardmetals and cermets. Int. J. Refract. Met. Hard Mater. 2000, 18, 153-161. [CrossRef]

33. Zhou, S.-Z.; Tan, J.-H.; Peng, W.-Z.; Wang, S.-Q.; Li, P. Sintering technology of Ti (C, N) base cermets. Trans. Nonferrous Met. Soc. China 2009, 19, s696-s700. [CrossRef]

34. Zhang, Y.; Zheng, Y.; Zhong, J.; Yuan, Q.; Wu, P. Effect of carbon content and cooling mode on the microstructure and properties of Ti (C, N)-based cermets. Int. J. Refract. Met. Hard Mater. 2009, 27, 1009-1013. [CrossRef] 
35. Zheng, Y.; Liu, W.; Wang, S.; Xiong, W. Effect of carbon content on the microstructure and mechanical properties of $\mathrm{Ti}(\mathrm{C}, \mathrm{N})$-based cermets. Ceram. Int. 2004, 30, 2111-2115. [CrossRef]

36. Liu, N.; Liu, X.; Zhang, X.; Zhu, L. Effect of carbon content on the microstructure and mechanical properties of superfine Ti (C, N)-based cermets. Mater. Charact. 2008, 59, 1440-1446. [CrossRef]

37. Li, P.; Ye, J.; Liu, Y.; Yang, D.; Yu, H. Study on the formation of core-rim structure in Ti (CN)- based cermets. Int. J. Refract. Met. Hard Mater. 2012, 35, 27-31. [CrossRef]

38. Wang, L.; Sui, W.; Luan, S.; Song, R.; Tan, J. Sintering behavior and dielectric properties of Ce doped strontium barium niobate ceramics with silica sintering additive. Mater. Chem. Phys. 2012, 134, 531-535. [CrossRef]

39. Andrén, H.-O. Microstructure development during sintering and heat-treatment of cemented carbides and cermets. Mater. Chem. Phys. 2001, 67, 209-213. [CrossRef]

40. Tsai, K.-M.; Hsieh, C.-Y.; Lu, H.-H. Sintering of binderless tungsten carbide. Ceram. Int. 2010, 36, 689-692. [CrossRef]

41. Estrada-Guel, I.; Carreno-Gallardo, C.; Cardoso-Cortes, J.; Rocha-Rangel, E.; Herrera-Ramirez, J.; Martinez-Sanchez, R. Effect of metallic addition on mechanical properties in an aluminum-graphite composite synthesized by means of mechanical milling. J. Alloys Compd. 2010, 495, 403-407. [CrossRef]

42. Kot, M.; Major, L.; Chronowska-Przywara, K.; Lackner, J.; Waldhauser, W.; Rakowski, W. The advantages of incorporating $\mathrm{Cr}_{\mathrm{x}} \mathrm{C}$ nanograins into an aC: $\mathrm{H}$ matrix in tribological coatings. Mater. Des. 2014, 56, 981-989. [CrossRef]

43. Lengauer, W.; Scagnetto, F. Ti(C,N)-based cermets: Critical review of achievements and recent developments. Solid State Phenom. 2018, 274, 53-100. [CrossRef]

44. Ettmayer, P. Hardmetals and cermets. Annu. Rev. Maler. Sci. 1989, 19, 145-154. [CrossRef]

45. Seplyarskii, B.S.; Kostin, S.V.; Brauer, G.B. Combustion of bulk density powder mixtures in a coflow of nitrogen gas: 3. The Ti-(Ti + 0.5C) layered system. Int. J. Self-Propagating High-Temp. Synth. 2008, 17, 121-124. [CrossRef]

46. Humenic, M.; Parikh, N.M. Fundamental concepts related to the microstructure and physical properties of cermet systems. J. Am. Ceram. Soc. 1956, 39, 60-63. [CrossRef]

47. Kieffer, R.; Ettmayer, P.; Freudhofmeier, M. Novel types of nitride and carbo-nitride hard metals. Metall 1971, 25, 335-342.

48. Rudy, E. Boundary phase stability and critical phenomena in high order solid solution systems. J. Less-Common Met. 1973, 33, 43-70. [CrossRef]

49. Aramian, A.; Sadeghian, Z.; Prashanth, K.G.; Berto, F. In situ fabrication of TiC-NiCr cermets by selective laser melting. Int. J. Refract. Met. Hard Mater. 2019, 87, 105171. [CrossRef]

50. Delbari, S.A.; Sabahi Namini, A.; Shahedi Asl, M. Hybrid Ti matrix composites with $\mathrm{TiB}_{2}$ and TiC compounds. Mater. Today Commun. 2019, 20, 100576. [CrossRef]

51. Qi, Q.; Liu, Y.; Zhang, H.; Zhao, J.; Huang, Z. The adjustment of microstructure and properties of TiC/Ni-Cr composites by Mo addition applied for intermediate temperature solid oxide fuel cell interconnects. J. Alloys Compd. 2016, 678, 375-382. [CrossRef]

52. Yerui, F.; Yongfeng, G.; Zongfeng, L. Experimental investigation of EDM parameters for TiC/Ni cermet machining. Procedia CIRP 2016, 42, 18-22. [CrossRef]

53. Durlu, N. Titanium carbide-based composites for high-temperature applications. J. Eur. Ceram. Soc. 2002, 19, 2415-2419. [CrossRef]

54. Komratov, G.N. Kinetics of oxidation SHS of titanium carbide and titanium and chromium double carbide powders in air. Powder Metall. Met. Ceram. 1993, 32, 509-511. [CrossRef]

55. Borisov, Y.S.; Borisova, A.L.; Kolomytsev, M.V.; Masyuchok, O.P.; Timofeeva, I.I.; Vasilkovskaya, M.A. Protective and functional powder coatings high-velocity air plasma spraying of (Ti, Cr)C-32 wt.\% Ni clad powder. Powder Metall. Met. Ceram. 2017, 56, 305-315. [CrossRef]

56. Varma, A.; Mukasyan, A.S. Combustion synthesis of advanced materials: Fundamentals and applications. Korean J. Chem. Eng. 2004, 21, 527-536. [CrossRef]

57. Zhang, W.N.; Wang, H.Y.; Wang, P.J.; Zhang, J.; He, L.; Jiang, Q.C. Effect of Cr content on the SHS reaction of Cr-Ti-C system. J. Alloys Compd. 2008, 465, 127-131. [CrossRef]

58. Liu, G.; Li, J.; Chen, K. Combustion synthesis of refractory and hard materials: A review. Int. J. Refract. Met. Hard Mater. 2013, 39, 90-102. [CrossRef] 
59. Nersisyan, H.H.; Lee, J.H.; Ding, J.-R.; Kim, K.-S.; Manukyan, K.V.; Mukasyan, A.S. Combustion synthesis of zero-, one-, two- and three-dimensional nanostructures: Current trends and future perspectives. Prog. Energy Combust. Sci. 2017, 63, 79-118. [CrossRef]

60. Bartuli, C.; Smith, R.W. Comparison between Ni-Cr-40vol\%TiC wear-resistant plasma sprayed coatings produced from self-propagating high-temperature synthesis and plasma densified powders. J. Therm. Spray Technol. 1996, 5, 335-342. [CrossRef]

61. Bartuli, C.; Smith, R.W.; Shtessel, E. SHS powders for thermal spray applications. Ceram. Int. 1997, 23, 61-68. [CrossRef]

62. Kunrath, A.O.; Upadhaya, K.; Reimanis, I.E.; Moore, J.J. Synthesis and application of composite $\mathrm{TiC}_{-\mathrm{CnC}}$ targets. Surf. Coat. Technol. 1997, 94-95, 237-241. [CrossRef]

63. Wang, B.-Q.; Verstak, A. Elevated temperature erosion of HVOF CnCi/TiC-NiCrMo cermet coating. Wear 1999, 233, 342-351. [CrossRef]

64. Steinhauser, S.; Wielage, B.; Hofmann, U.; Schnick, T.; Ilyuschenko, A.; Azarova, T. Plasma- sprayed wear-resistant coatings with respect to ecological aspects. Surf. Coat. Technol. 2000, 131, 365-371. [CrossRef]

65. Jones, M.; Horlock, A.J.; Shipway, P.H.; McCartney, D.G.; Wood, J.V. Microstructure and abrasive wear behavior of FeCr-TiC coatings deposited by HVOF spraying of SHS powders. Wear 2001, 249, 246-253. [CrossRef]

66. Jones, M.; Horlock, A.J.; Shipway, P.H.; McCartney, D.G.; Wood, J.V. A comparison of the abrasive wear behaviour of HVOF sprayed titanium carbide and titanium boride-based cermet coatings. Wear 2001, 251, 1009-1016. [CrossRef]

67. Horlock, A.J.; McCartney, D.G.; Shipway, P.H.; Wood, J.V. Thermally sprayed Ni(Cr)-TiB coatings using powder produced by self-propagating high temperature synthesis: Microstructure and abrasive wear behavior. Mater. Sci. Eng. 2002, A336, 88-98. [CrossRef]

68. Degnan, C.C.; Shipway, P.H. A comparison of the reciprocating sliding wear behavior of steel-based metal matrix composites processed from self-propagating high-temperature synthesized Fe-TiC and $\mathrm{Fe}-\mathrm{TiB}_{2}$ master alloys. Wear 2002, 252, 9-10. [CrossRef]

69. Licheri, R.; Orru, R.; Cao, G.; Crippa, A.; Scholz, R. Self-propagating combustion synthesis and plasma spraying deposition of TiC-Fe powders. Ceram. Int. 2003, 29, 519-526. [CrossRef]

70. Licheri, R.; Orru, R.; Locci, A.M.; Cao, G. Combustion synthesis of TiC-metal composites and related plasma spraying deposition. Int. J. Mater. Prod. Technol. 2004, 20, 464-478. [CrossRef]

71. Dercz, G.; Formanek, B.; Prusik, K.; Pajak, L. Microstructure of $\mathrm{Ni}(\mathrm{Cr})-\mathrm{TiC}-\mathrm{CnC}_{2}-\mathrm{Cr}_{7} \mathrm{C}_{3}$ composite powder. J. Mater. Process. Technol. 2005, 162-163, 15-19. [CrossRef]

72. Borisova, A.L.; Borisov, Y.S. Self-propagating high-temperature synthesis for the deposition of thermal-sprayed coatings. Powder Metall. Met. Ceram. 2008, 47, 80-94. [CrossRef]

73. Munir, Z.; Anselmi-Tamburini, V. Self-Propagating Exothermic Reactions: The synthesis of high-temperature materials by combustion. Mater. Sci. Rep. 1989, 3, 277-365. [CrossRef]

74. Talako, T.; Ilyuschenko, A.; Letsko, A. (2009). SHS powders for thermal spray coating. KONA Powder Part. J. 2009, 27, 55-72. [CrossRef]

75. Kunrath, A.O.; Reimanis, I.E.; Moore, J.J. Microstructural evolution of titanium carbide-chromium carbide $\left(\mathrm{TiC}_{-} \mathrm{Cr}_{3} \mathrm{C}_{2}\right)$ composites produced via combustion synthesis. J. Am. Ceram. Soc. 2004, 85, 1285-1290. [CrossRef]

76. Jie-Cai, H.; Zhang, X.-H.; Wood, J. In-situ combustion synthesis and densification of TiC-xNi cermets. Mater. Sci. Eng. A 2000, 280, 328-333. [CrossRef]

77. Zhang, W.N.; Wang, H.Y.; Yin, S.Q.; Jiang, Q.C. Effect Ti/C ratio on the SHS reaction of Cr-Ti-C system. Mater. Lett. 2007, 61, 3075-3078. [CrossRef]

78. Vlasov, V.A.; Sharivker, S.Y.; Ponomarev, V.I.; Khomenko, N.Y.; Belikova, A.F.; Zakorzhevski, V.V. Annealing of Ti-Cr carbide produced by SHS. Int. J. SHS 1997, 6, 431-437.

79. Seplyarsky, B.S.; Kochetkov, R.A.; Lisina, T.G.; Abzalov, N.I. The effect of synthesis conditions on phase composition and structure of combustion products of nickel-bonded titanium carbide. Adv. Mater. Technol. 2017, 4, 22-28. [CrossRef]

80. Seplyarskii, B.S.; Kochetkov, R.A. Granulation as a tool for stabilization of SHS reactions. Int. J. SHS 2017, 26, $134-136$. [CrossRef]

81. Turchi, P.E.A.; Kaufman, L.; Liu, Z.-K. Modeling of Ni-Cr-Mo based alloys: Part I-phase stability. Calphad 2006, 30, 70-87. [CrossRef] 
82. Vyazovkin, S. On the phenomenon of variable activation energy for condensed phase reactions. New J. Chem. 2000, 24, 913-917. [CrossRef]

83. Shuck, C.E.; Mukasyan, A.S. Reactive Ni/Al nanocomposites: Structural characteristics and activation energy. J. Phys. Chem. A 2017, 121, 1175-1181. [CrossRef] [PubMed]

84. Manukyan, K.V.; Lin, Y.-C.; Rouvimov, S.; McGinn, P.J.; Mukasyan, A.S. Microstructure-reactivity relationship of $\mathrm{Ti}+\mathrm{C}$ reactive nanomaterials. J. Appl. Phys. 2013, 113, 024302. [CrossRef]

85. Borovinskaya, I.P.; Gromov, A.A.; Levashov, E.A.; Maksimov, Y.M.; Mukasyan, A.S.; Rogachev, A.S. Concise Encyclopedia of Self-Propagating High-Temperature Synthesis; Elsevier: Amsterdam, The Netherlands, 2017; pp. 90-92.

86. Rogachev, A.S. Combustion Wave Velocity and Temperature Profile. In Concise Encyclopedia of Self-Propagating High-Temperature Synthesis: History, Theory, Technology, and Products; Borovinskaya, I.P., Gromov, A.A., Levashov, E.A., Maksimov, Y.M., Mukasyan, A.S., Rogachev, A.S., Eds.; Elsevier: Amsterdam, The Netherlands, 2017; pp. 79-81.

87. Krishenik, P.M. Combustion Wave Propagation Velocity. In Concise Encyclopedia of Self-Propagating High-Temperature Synthesis: History, Theory, Technology, and Products; Borovinskaya, I.P., Gromov, A.A., Levashov, E.A., Maksimov, Y.M., Mukasyan, A.S., Rogachev, A.S., Eds.; Elsevier: Amsterdam, The Netherlands, 2017; pp. 77-78.

88. Shaboueia, M.; Subber, W.; Williams, C.W.; Matous, K.; Powers, J.M. Chemo-thermal model and Gaussian process emulator for combustion synthesis of Ni/Al composites. Combust. Flame 2019, 207, 153-170. [CrossRef]

89. Lapshin, O.V.; Prokof'ev, V.G.; Smolyakov, V.K. Combustion of Granulated Gasless Mixtures in a Flow of Inert Gas. Int. J. Self-Propag. High-Temp Synth. 2018, 27, 14-17. [CrossRef]

90. Seplyarskii, B.S.; Tarasov, A.G.; Kochetkov, R.A. Experimental investigation of combustion of a gasless pelletized mixture of $\mathrm{Ti}+0.5 \mathrm{C}$ in argon and nitrogen coflows. Combust. Explos. Shock Waves 2013, 49, 555-562. [CrossRef]

91. Tarasov, A.G.; Seplyarskii, B.S.; Barinov, Y.N.; Semenova, V.N. Self-purification effect in the synthesis of titanium carbonitride in a combustion regime. Mendeleev Commun. 2011, 21, 289-290. [CrossRef]

92. Kostin, S.V.; Barzykin, V.V. Filtration-Diffusion Combustion Limit of a Titanium Powder in Nitrogen upon Degassing. Combust. Explos. Shock Waves 2001, 37, 297-302. [CrossRef]

93. Mukas'yan, A.S.; Shugaev, V.A.; Kir'yakov, N.V. Effect of gaseous fluid phases on combustion of metals in nitrogen. Combust. Explos. Shock Waves 1993, 29, 7-11. [CrossRef]

94. Cornea, N. Influence of the degree of carbonization and granulation of fuel on combustion process. Rev. Chim. 2010, 61, 869-871.

95. Xiao, G.; Fan, Q.; Gu, M.; Wang, Z.; Jin, Z. Dissolution-precipitation mechanism of self-propagating high-temperature synthesis of TiC Ni cermet. Mater. Sci. Eng. A 2004, 382, 132-140. [CrossRef]

96. Taheri-Nassaj, E.; Mirhosseini, S.H. An in situ WC-Ni composite fabricated by the SHS method. J. Mater. Process. Technol. 2003, 142, 422-426. [CrossRef]

97. Córdoba, J.M.; Alcalá, M.D.; Avilés, M.A.; Sayagués, M.J.; Gotor, F.J. New production of TiCxN1-x-based cermets by one step mechanically induced self-sustaining reaction: Powder synthesis and pressureless sintering. J. Eur. Ceram. Soc. 2008, 28, 2085-2098. [CrossRef]

98. Boutefnouchet, H.; Curfs, C.; Triki, A.; Boutefnouchet, A.; Vrel, D. Self-propagating high-temperature synthesis mechanisms within the Ti-C-Ni system: A time-resolved X-ray diffraction study. Powder Technol. 2012, 217, 443-450. [CrossRef]

(C) 2020 by the authors. Licensee MDPI, Basel, Switzerland. This article is an open access article distributed under the terms and conditions of the Creative Commons Attribution (CC BY) license (http://creativecommons.org/licenses/by/4.0/). 